\title{
Studi Simulasi Numerik dan Eksperimental Perpindahan Panas Konduksi 2 Dimensi di Permukaan Pahat Bubut Karbida Pada Proses Pembubutan Muka
}

\author{
(Numerical and Experimental Simulation Study of 2 Dimentional Conduction Heat Transfer \\ on the Surface Carbide Lathe Chisel in the Advance Seeding Process) \\ Perwita Kurniawan $^{\mathrm{a}}$, Adhi Setya Hutama ${ }^{\mathrm{b}}$, Cahyo Budiantoro ${ }^{\mathrm{c}}$ \\ ${ }^{a, b}$ Program Studi Teknologi Rekayasa Perancangan Manufaktur, Politeknik ATMI Surakarta \\ Jl. Adisucipto/ Jl. Mojo No.1 Surakarta \\ Phone: (0271) 271714466 \\ e-mail: perwita.kurniawan@atmi.ac.id, setya.hutama@atmi.ac.id \\ ${ }^{c}$ Program Studi Teknik Mesin, Fakultas Teknik, Universitas Muhammadiyah Yogyakarta Jalan \\ Lingkar Selatan Tamantirto, Kasihan, Bantul, DI Yogyakarta, Indonesia, 55183 \\ cahyo_budi@umy.ac.id,
}

\section{Abstrak}

Proses pembubutan menimbulkan sebaran panas pada permukaan alat potong atau pahat. Sebaran panas pada permukaan pahat dapat dianalisa dengan penentuan persamaan perpindahan panas di awal. Dalam penelitian ini, persamaan perpindahan panas 2 dimensi diselesaikan dengan metode beda hingga. Metode komputasi digunakan untuk menyelesaikan model perpindahan panas secara dua dimensi, sebab sangat sulit untuk diselesaikan dengan analisis secara matematis. Metode Alternating Direct Implicit digunakan untuk mendiskritisasi persamaan perpindahan panas 2 dimensi. Temperatur hasil komputasi dapat diilustrasikan dengan tampilan Matlab. Luaran penelitian ini adalah data sebaran temperatur hasil eksperimen dan komputasi. Temperatur maksimal hasil komputasi sebesar 309,99 Kelvin di titik 1, dan mulai stabil pada detik ke-110. Temperatur terendah hasil komputasi berada pada titik 3 dan 4 sebesar 309,60 Kelvin, dan mulai stabil pada detik ke-110. Temperatur maksimal hasil pengujian sebesar 388,00 Kelvin di titik 1 pada detik ke-120, saat akhir pengujian. Temperatur terendah hasil komputasi berada pada titik 3 sebesar 310,44 Kelvin pada detik ke-120, saat akhir pengujian. Berdasarkan hasil penelitian, rata-rata perbedaan temperatur antara kondisi nyata dengan hasil komputasi adalah sebesar 1,03 Kelvin.

Kata kunci: metode beda hingga, metode Alternating Direct Implicit ( $A D I)$, distribusi temperatur

\section{Abstract}

The turning process causes heat distribution on the surface of the turning machine cutting tool. The heat distribution on the tool surface can be analyzed by determining the initial heat transfer equation. In this study, the 2-dimensional heat transfer equation was solved by using the Finite Difference Method. The computational method is used to solve the two-dimensional heat transfer model, because it is very difficult to solve it by mathematical analysis. The Alternating Direct Implicit method is used to discretize the 2-dimensional heat transfer equation. The computed temperature can be illustrated using the Matlab display. The results of this study are temperature data from experimental results and computational results. The maximum computational temperature is $309.99 \mathrm{Kelvin}$ at point 1, and begins to steady at 110'th second. The lowest computational temperature is $309.60 \mathrm{Kelvin}$ at point 3 and 4, and begins to steady at the 110'th second. The maximum temperature of the measurement results is $388.00 \mathrm{Kelvin}$ at point 1, at the 120'th second, at the end of the test. The lowest computational temperature is 310.44 Kelvin at point 3, at the 120'th second, at the end of the 
test. Based on the results of the study, the average temperature difference between the real conditions and the computational results is $1.03 \mathrm{Kelvin}$.

Keywords: finite different method, Alternating Direct Implicit ( $A D I)$ method, temperature distribution.

\section{Pendahuluan}

Proses pembubutan adalah sebuah proses penyayatan material yang mempertemukan material benda kerja yang lebih lunak dengan material alat potong yang lebih keras. Proses ini menimbulkan sebaran panas pada permukaan alat potong atau pahat. Sebaran panas terjadi karena adanya proses perpindahan panas. Perpindahan panas didefinisikan sebagai suatu proses berpindahnya suatu energi (panas) dari satu daerah ke daerah lain akibat adanya perbedaan temperatur pada daerah tersebut [1]. Dengan adanya ilmu perpindahan panas maka dapat dijelaskan jika energi panas tersebut dapat berpindah dari satu bagian ke bagian lain. Penelitian perpindahan panas pada proses pembubutan pernah dilakukan [2] untuk menganalisa pengaruh lubang pendingin yang tertanam di dalam pahat dengan analisa numerik. Penelitian ini bertujuan untuk mengetahui pengaruh pipa pendingin yang ditanam di dalam pahat terhadap sebaran panas yang terjadi pada permukaan pahat secara dua dimensi. Hasilnya pahat yang memiliki pipa pendingin menghasilkan grafis sebaran panas yang lebih rendah temperaturnya.

Salah satu metode yang digunakan untuk menganalisa sebuah proses perpindahan panas adalah Metode Beda Hingga. Penelitian perpindahan panas dengan menggunakan metode beda hingga pada permukaan benda secara 2 dimensi pernah dilakukan, diantaranya: pada heatsink [3], pada penampang lempeng homogen dua dimensi [4], dan pada permukaan plat almunium [5]. Tujuan dari beberapa penelitian tersebut adalah mengetahui pola distribusi temperatur pada benda padat secara dua dimensi. Metode Beda Hingga sering digunakan untuk mencari solusi suatu persamaan diferensial karena pendekatan dari domain persamaan diferensial parsial dibawa ke dalam domain komputasi yang berupa grid [6]

Penggunaan metode beda hingga membutuhkan suatu metode penyelesaian persamaan numerik. Salah satu metode penyelesaian persamaan numerik adalah metode Alternating Direct Implicit $(A D I)$. Metode $A D I$ telah sukses digunakan untuk menyelesaikan model persamaan perpindahan panas konduksi transien 2 dimensi pada proses pendinginan baja slab [7].

Setelah persamaan numerik diselesaikan, maka dilakukan proses pembuatan model dan simulasi dengan menggunakan perangkat lunak komputer. Banyak perangkat lunak yang dapat digunakan untuk membuat simulasi perpindahan panas, diantaranya adalah Fortran dan Matlab. Pembuatan permodelan komputasi perpindahan panas dilakukan dengan menggunakan perangkat lunak Fortran, sedangkan pensimulasian permodelan perpindahan panas dilakukan dengan menggunakan perangkat lunak Matlab. Persamaan perpindahan panas yang diselesaikan dengan metode $A D I$ dapat dimodelkan dan disimulasikan dengan menggunakan perangkat lunak Fortran dan Matlab oleh [8], pada penelitian proses pendinginan tembaga. Proses pembuatan simulasi membutuhkan pengaturan parameter elemen. Jumlah elemen akan menentukan hasil simulasi. Menurut [9], semakin banyak elemen yang digunakan untuk simulasi, maka hasil simulasi akan semakin akurat, dan kontur perpindahan panas akan semakin terlihat.

Berdasarkan penelitian tersebut, penelitian ini akan membahas tentang analisa perpindahan panas pada permukaan pahat bubut sayat muka karbida ISO 2. Persamaan perpindahan panas yang digunakan, diselesaikan dengan menggunakan metode beda hingga. Persamaan numerik akan dimodelkan menggunakan perangkat lunak Fortran, dan disimulasikan dengan menggunakan perangkat lunak Matlab. Proses penelitian akan dilakukan dengan membandingkan hasil simulasi numerik dengan hasil eksperimental langsung pada saat proses pembubutan. Perbandingan antara hasil simulasi numerik dan eksperimental dilakukan untuk menganalisa kebenaran proses komputasi dengan realita yang terjadi [10]. Melalui penelitian ini akan didapatkan data sebaran panas pada permukaan pahat bubut karbida pada proses pembubutan muka secara sahih. Berdasarkan 
data sebaran panas dapat diamati temperatur maksimal, temperatur minimal, posisi temperatur maksimal, posisi temperatur minimal, dan waktu munculnya data temperatur.

\section{Metodologi}

Metodologi penelitian memuat data beserta sumbernya, penjelasan mengenai variabel penelitian yang digunakan, dan metode analisis yang digunakan dalam penelitian.

\subsection{Simulasi Numerik}

Simulasi numerik dilakukan dengan menggunakan perangkat lunak Fortran dan Matlab. Pembuatan permodelan komputasi perpindahan panas menggunakan perangkat lunak Fortran, sedangkan pensimulasian permodelan komputasi perpindahan panas menggunakan perangkat lunak Matlab. Langkah-langkah untuk melakukan simulasi numerik diawali dengan melakukan diskritisasi persamaan perpindahan panas dan menentukan domain syarat batas.

\subsubsection{Diskritisasi persamaan perpindahan panas}

Bentuk persamaan difusi untuk perpindahan panas secara 2 dimensi

$$
\frac{\partial T}{\partial t}=\alpha\left(\frac{\partial^{2} T}{\partial x^{2}}+\frac{\partial^{2} T}{\partial y^{2}}\right)
$$

Keterangan:

$$
\begin{array}{ll}
\text { T : temperatur } & \left({ }^{\circ} \mathrm{C}\right) \\
\alpha: \text { difusivitas thermal } & \left(\mathrm{m}^{2} / \text { detik }\right) \\
x \text { : jarak pada arah sumbu } x & (\mathrm{~m}) \\
y \text { : jarak pada arah sumbu } y & (\mathrm{~m})
\end{array}
$$

Mengacu pada persamaan (1), maka dibuat diskritisasi persamaan beda hingga dengan metode Alternating Direct Implicit ( $A D I$ ) pada arah $\mathrm{x}$ dan arah y ( $x$-sweep dan $y$-sweep) dengan metode fractional step. Pada tahap pertama metode fractional step dilakukan diskritisasi pada arah $\mathrm{x}$, dan pada tahap kedua dilakukan diskritisasi pada arah $\mathrm{y}$.

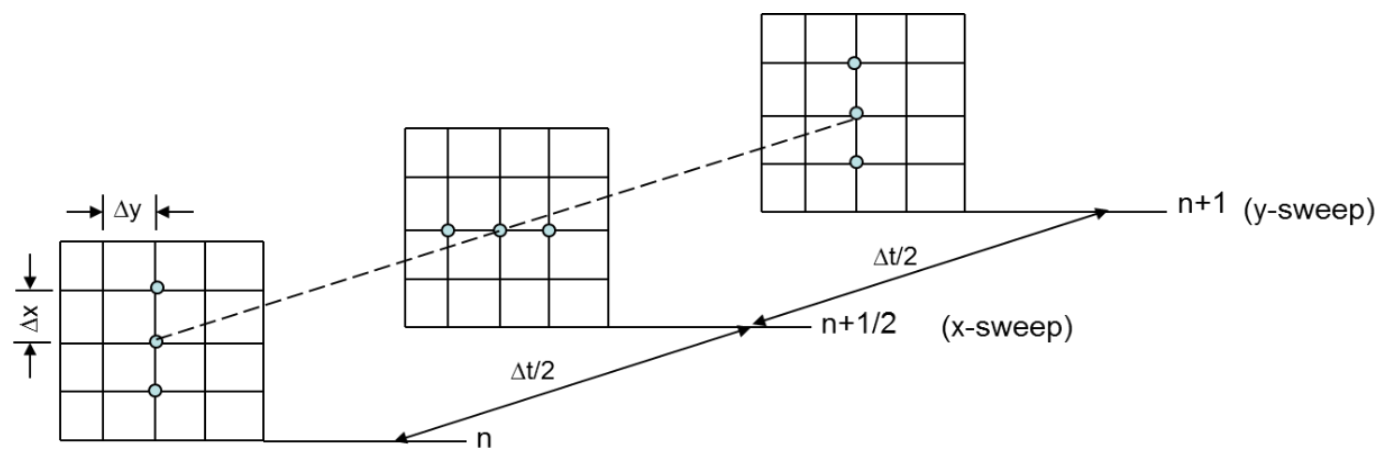

Gambar 1. Skema metode ADI

\section{a). X-Sweep}

$X$-sweep merupakan langkah dari $\mathrm{n}$ menuju $\mathrm{n}+1 / 2$. Langkah untuk menentukan nilainilai dari $x$-sweep pada persamaan (1) adalah dengan membuat diskritisasi sebagai berikut:

Diskritisasi turunan waktu 


$$
\frac{\partial T}{\partial t}=\frac{T_{i, j}^{n+1 / 2}-T_{i, j}^{n}}{\frac{\Delta t}{2}}
$$

Diskritisasi turunan ruang untuk arah $\mathrm{x}$

$$
\frac{\partial^{2} T}{\partial x^{2}}=\frac{T_{i+1, j}^{n+1 / 2}-2 T_{i, j}^{n+1 / 2}+T_{i-1, j}^{n+1 / 2}}{(\Delta x)^{2}}
$$

Diskritisasi turunan ruang untuk arah y

$$
\frac{\partial^{2} T}{\partial y^{2}}=\frac{T_{i, j+1}^{n}-2 T_{i, j}^{n}+T_{i, j-1}^{n}}{(\Delta y)^{2}}
$$

Dengan mensubstitusikan persamaan (2), (3), dan (4) ke persamaan (1), dan mengalikan masing-masing ruas dengan $\Delta t / 2$ diperoleh persamaan sebagai berikut:

$$
T_{i, j}^{n}+\frac{\alpha \Delta T}{2(\Delta y)^{2}}\left(T_{i, j+1}^{n}-2 T_{i, j}^{n}+T_{i, j-1}^{n}\right)=-\frac{\alpha \Delta T}{2(\Delta x)^{2}} T_{i-1, j}^{n+1 / 2}+\left[1+\frac{\alpha \Delta T}{(\Delta x)^{2}} T_{i, j}^{n+1 / 2}\right]-\frac{\alpha \Delta T}{2(\Delta x)^{2}} T_{i+1, j}^{n+1 / 2}
$$

Persamaan di atas dapat dituliskan dalam bentuk sistem tridiagonal untuk grid pada $x$-sweep :

$$
a_{i} T_{i-1, j}^{n+1 / 2}+b_{i} T_{i, j}^{n+1 / 2}+c_{i} T_{i+1, j}^{n+1 / 2}=d_{i}
$$

Dimana :

$$
\begin{aligned}
& a_{j}=-\frac{\alpha \Delta t}{2(\Delta y)^{2}} \\
& b_{j}=1+\frac{\alpha \Delta t}{(\Delta y)^{2}} \\
& c_{j}=-\frac{\alpha \Delta t}{2(\Delta y)^{2}} \\
& d_{j}=T_{i, j}^{n+1 / 2}+\frac{\alpha \Delta t}{2(\Delta x)^{2}}\left(T_{i-1, j}^{n+1 / 2}-2 T_{i, j}^{n+1 / 2}+T_{i+1, j}^{n+1 / 2}\right)
\end{aligned}
$$

\section{b). Y-Sweep}

$Y$-sweep merupakan langkah dari $n+1 / 2$ menuju $n+1$. Langkah untuk menentukan nilai-nilai dari $y$-sweep pada persamaan (1) adalah dengan membuat diskritisasi sebagai berikut:

Diskritisasi turunan waktu

$$
\frac{\partial T}{\partial t}=\frac{T_{i, j}^{n+1}-T_{i, j}^{n+1 / 2}}{\frac{\Delta t}{2}}
$$

Diskritisasi turunan ruang untuk arah $\mathrm{x}$

$$
\frac{\partial^{2} T}{\partial x^{2}}=\frac{T_{i+1, j}^{n+1 / 2}-2 T_{i, j}^{n+1 / 2}+T_{i-1, j}^{n+1 / 2}}{(\Delta x)^{2}}
$$

Diskritisasi turunan ruang untuk arah y 
Dengan mensubstitusikan persamaan (6), (7), dan (8) ke persamaan (1), dan mengalikan masing-masing ruas dengan $\Delta t / 2$ diperoleh persamaan sebagai berikut:

$$
T_{i, j}^{n+1 / 2}+\frac{\alpha \Delta T}{2(\Delta x)^{2}}\left(T_{i+1, j}^{n+1 / 2}-2 T_{i, j}^{n+1 / 2}+T_{i-1, j}^{n+1 / 2}\right)=-\frac{\alpha \Delta T}{(\Delta y)^{2}} T_{i, j-1}^{n+1}+\left[1+\frac{\alpha \Delta T}{(\Delta y)^{2}} T_{i, j}^{n+1}\right]-\frac{\alpha \Delta T}{2(\Delta y)^{2}} T_{i, j+1}^{n+1}
$$

Persamaan di atas dapat dituliskan dalam bentuk sistem tridiagonal untuk grid pada $y$ sweep :

$$
a_{j} T_{i, j-1}^{n+1}+b_{j} T_{i, j}^{n+1}+c_{j} T_{i, j+1}^{n+1}=d_{j}
$$

Dimana :

$$
\begin{aligned}
& a_{j}=-\frac{\alpha \Delta t}{2(\Delta y)^{2}} \\
& b_{j}=1+\frac{\alpha \Delta t}{(\Delta y)^{2}} \\
& c_{j}=-\frac{\alpha \Delta t}{2(\Delta y)^{2}} \\
& d_{j}=T_{i, j}^{n+1 / 2}+\frac{\alpha \Delta t}{2(\Delta x)^{2}}\left(T_{i-1, j}^{n+1 / 2}-2 T_{i, j}^{n+1 / 2}+T_{i+1, j}^{n+1 / 2}\right)
\end{aligned}
$$

\subsubsection{Domain dan Syarat Batas}

Kondisi batas ditentukan dengan menggambar 2 dimensi alat potong dan menentukan situasi yang terjadi pada permukaan pahat. Penyayatan hanya dilakukan selebar $0,5 \mathrm{~mm}$, sedangkan semua sisi lain terhubung dengan udara. Konduksi terjadi pada material pahat, sedangkan konveksi terjadi pada semua sisi pahat, kecuali sisi sayat. 


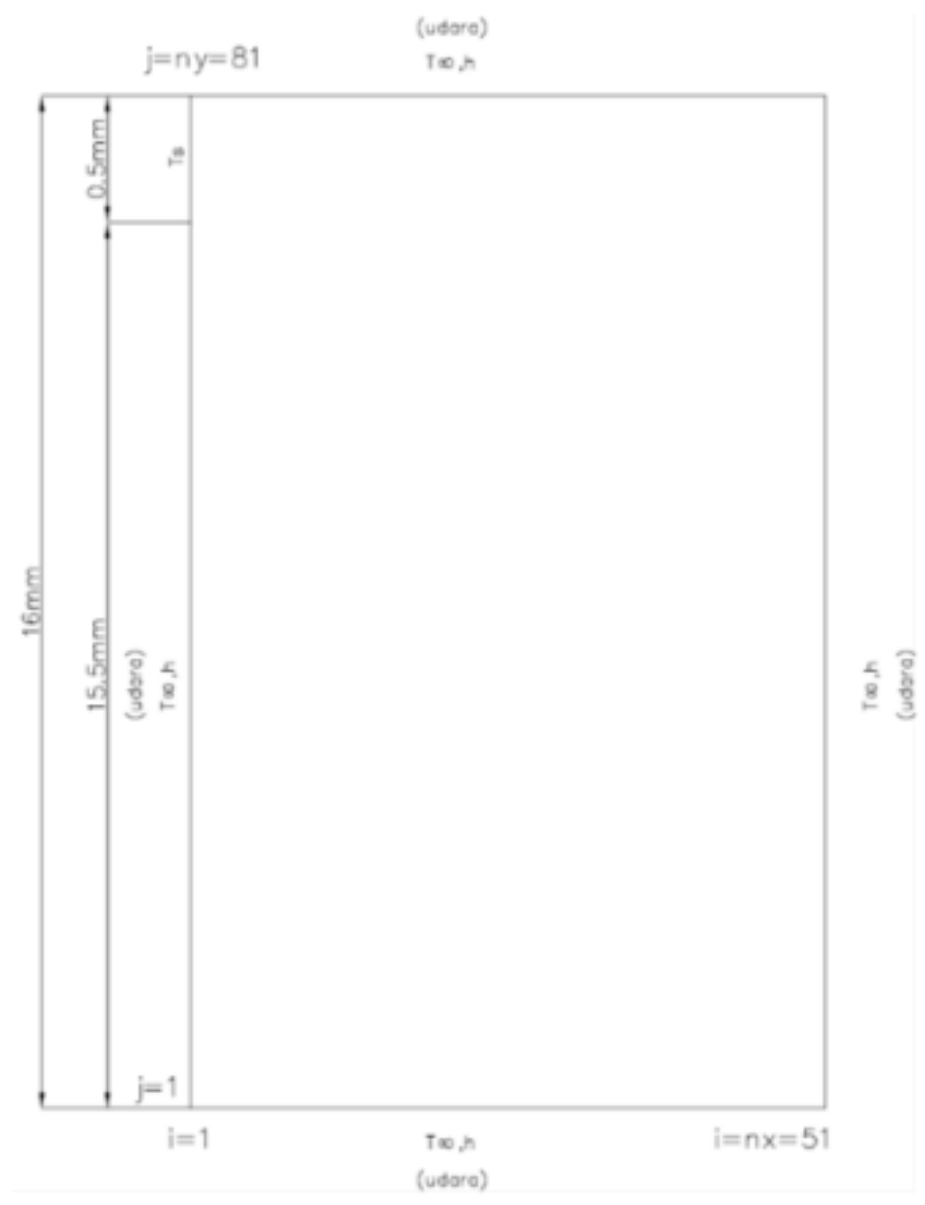

Gambar 2. Kondisi Batas

\section{Keterangan:}

$$
\begin{array}{cll}
h & : \text { koefisien perpindahan panas } & \left(\mathrm{W} / \mathrm{m}^{2} \mathrm{~K}\right) \\
k & : \text { merupakan konduktivitas termal } & (\mathrm{W} / \mathrm{m} . \mathrm{K}) \\
\mathrm{i} & : \text { posisi nodal pada arah sumbu x } & \\
\mathrm{j} & : \text { posisi nodal pada arah sumbu y } &
\end{array}
$$

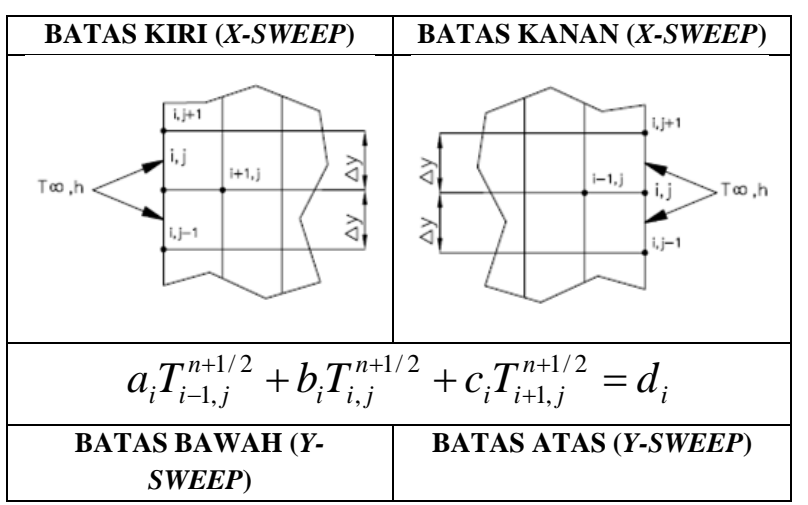




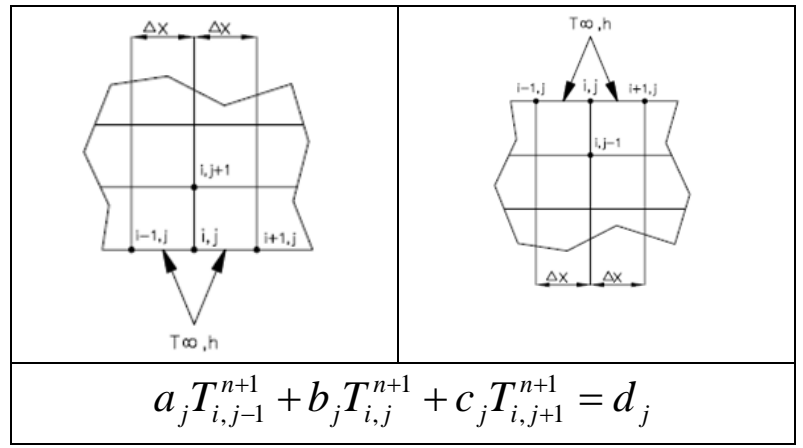

Gambar 3. Kondisi Batas Kiri, Kanan, Atas dan Bawah

a). Persamaan kondisi batas kiri:

$$
\begin{aligned}
& a_{i}=0 \\
& b_{i}=1+2 \frac{\alpha \Delta t}{(\Delta x)^{2}}\left(2+\frac{h \Delta x}{k}\right) \\
& c_{i}=-2 \frac{\alpha \Delta t}{(\Delta x)^{2}} \\
& d_{i}=T_{i, j}^{n}+\frac{\alpha \Delta t}{(\Delta y)^{2}}\left(T_{i, j-1}^{n}+T_{i, j+1}^{n}\right)+2\left(\frac{h \Delta y}{k}\right) T_{\infty}^{n}
\end{aligned}
$$

Maka:

$$
T_{i, j}^{n}+\frac{\alpha \Delta t}{(\Delta y)^{2}}\left(T_{i, j+1}^{n}+T_{i, j-1}^{n}\right)+2\left(\frac{h \Delta y}{k}\right) T_{\infty}^{n}=1+2 \frac{\alpha \Delta t}{(\Delta x)^{2}}\left(2+\frac{h \Delta x}{k}\right) T_{i, j}^{n+1 / 2}-2 \frac{\alpha \Delta t}{(\Delta x)^{2}} T_{i+1, j}^{n+1 / 2}(10)
$$

b). Persamaan kondisi batas kanan:

$$
\begin{aligned}
& a_{i}=-2 \frac{\alpha \Delta t}{(\Delta x)^{2}} \\
& b_{i}=1+2 \frac{\alpha \Delta t}{(\Delta x)^{2}}\left(2+\frac{h \Delta x}{k}\right) \\
& c_{i}=0 \\
& d_{i}=T_{i, j}^{n}+\frac{\alpha \Delta t}{(\Delta y)^{2}}\left(T_{i, j-1}^{n}+T_{i, j+1}^{n}\right)+2\left(\frac{h \Delta y}{k}\right) T_{\infty}^{n}
\end{aligned}
$$

Maka:

$$
T_{i, j}^{n}+\frac{\alpha \Delta t}{(\Delta y)^{2}}\left(T_{i, j+1}^{n}+T_{i, j-1}^{n}\right)+2\left(\frac{h \Delta y}{k}\right) T_{\infty}^{n}=1+2 \frac{\alpha \Delta t}{(\Delta x)^{2}}\left(2+\frac{h \Delta x}{k}\right) T_{i, j}^{n+1 / 2}-2 \frac{\alpha \Delta t}{(\Delta x)^{2}} T_{i-1, j}^{n+1 / 2}
$$


c). Persamaan kondisi batas bawah:

$$
\begin{aligned}
& a_{j}=0 \\
& b_{j}=1+2 \frac{\alpha \Delta t}{(\Delta y)^{2}}\left(2+\frac{h \Delta y}{k}\right) \\
& c_{j}=-2 \frac{\alpha \Delta t}{(\Delta y)^{2}} \\
& d_{j}=T_{i, j}^{n+1.2}+\frac{\alpha \Delta t}{(\Delta x)^{2}}\left(T_{i-1, j}^{n+1 / 2}+T_{i+1, j}^{n+1 / 2}\right)+2\left(\frac{h \Delta x}{k}\right) T_{\infty}^{n}
\end{aligned}
$$

Maka:

$$
T_{i, j}^{n+1 / 2}+\frac{\alpha \Delta t}{(\Delta x)^{2}}\left(T_{i-1, j}^{n+1 / 2}+T_{i+1, j}^{n+1 / 2}\right)+2\left(\frac{h \Delta x}{k}\right) T_{\infty}^{n}=1+2 \frac{\alpha \Delta t}{(\Delta y)^{2}}\left(2+\frac{h \Delta y}{k}\right) T_{i, j}^{n+1}-2 \frac{\alpha \Delta t}{(\Delta y)^{2}} T_{i, j+1}^{n+1}
$$

d). Persamaan kondisi batas atas:

$$
\begin{aligned}
& a_{j}=-2 \frac{\alpha \Delta t}{(\Delta y)^{2}} \\
& b_{j}=1+2 \frac{\alpha \Delta t}{(\Delta y)^{2}}\left(2+\frac{h \Delta y}{k}\right) \\
& c_{j}=0 \\
& d_{j}=T_{i, j}^{n+1.2}+\frac{\alpha \Delta t}{(\Delta x)^{2}}\left(T_{i-1, j}^{n+1 / 2}+T_{i+1, j}^{n+1 / 2}\right)+2\left(\frac{h \Delta x}{k}\right) T_{\infty}^{n}
\end{aligned}
$$

Maka:

$$
T_{i, j}^{n+1 / 2}+\frac{\alpha \Delta t}{(\Delta x)^{2}}\left(T_{i-1, j}^{n+1 / 2}+T_{i+1, j}^{n+1 / 2}\right)+2\left(\frac{h \Delta x}{k}\right) T_{\infty}^{n}=1+2 \frac{\alpha \Delta t}{(\Delta y)^{2}}\left(2+\frac{h \Delta y}{k}\right) T_{i, j}^{n+1}-2 \frac{\alpha \Delta t}{(\Delta y)^{2}} T_{i, j-1}^{n+1}
$$

Langkah sesudah melakukan diskritisasi persamaan perpindahan panas dan menentukan domain syarat batas adalah pembuatan model komputasi perpindahan panas dengan perangkat lunak Fortran dan pensimulasian model komputasi perpindahan panas dengan dengan perangkat lunak Matlab. Hasil dari simulasi numerik dicatat dalam sebuah tabel. Proses simulasi dilakukan dari detik ke-10 hingga detik ke-120.

\subsection{Eksperimen}

Pengambilan data secara eksperimen dilakukan dengan cara melakukan pembubutan pada mesin bubut Krisbow KW 15-484 dengan material aluminium 4032 dengan dimensi diameter $25,4 \mathrm{~mm}$ dan panjang $300 \mathrm{~mm}$. Alat potong yang digunakan untuk proses pembubutan adalah pahat bubut untuk sayat muka ISO 2. Proses pembubutan dilakukan dengan kedalaman pemakanan $0,5 \mathrm{~mm}$ jari-jari, kecepatan pemakanan $0,1 \mathrm{~mm} /$ putaran, dan putaran $1000 \mathrm{rpm}$.

Pada waktu proses pembubutan, dilakukan pengambilan data temperatur pada permukaan pahat. Pengukuran temperatur pemotongan menggunakan alat ukur suhu Ray Tek Mini Temp MT 4. Alat ini memiliki suhu operasional diantara 0 hingga $750^{\circ} \mathrm{F}(-18$ hingga $400^{\circ} \mathrm{C}$ ), tingkat respons 500 milidetik untuk setiap pembacaan pengukuran, akurasi $0,01^{\circ} \mathrm{C}$, dan emisivitas sebesar 0,95 . Pengukuran waktu menggunakan timer pada pemutar video dengan akurasi per 1 detik. Proses pengambilan data pengukuran dilakukan secara tidak langsung, tetapi melalui perekaman dengan kamera digital. Proses perekaman dilakukan dari detik pertama hingga detik ke-120. Hasil pengukuran temperatur secara eksperimen dicatat dalam sebuah tabel. 


\section{Hasil dan Pembahasan}

Data temperatur yang diambil untuk dianalisa adalah data dari 5 titik, yang terdiri dari 4 data di titik ujung pahat, dan 1 data di titik pusat pahat. Pada Gambar 4 terlihat tampilan pahat karbida berukuran $10 \mathrm{~mm} \times 16 \mathrm{~mm}$ dengan 5 titik pengambilan data. Berdasarkan pertimbangan proses simulasi numerik menggunakan nodal sejumlah 51 nodal x 81 nodal, jarak tiap nodalnya $0,2 \mathrm{~mm}$, dan diameter titik lasernya lebih kurang $3 \mathrm{~mm}$, maka titik yang diambil datanya berkoordinat: titik1 $(2 \mathrm{~mm}, 14 \mathrm{~mm})$, titik2 $(8 \mathrm{~mm}, 14 \mathrm{~mm})$, titik3 $(8 \mathrm{~mm}, 2 \mathrm{~mm})$, titik4 $(2 \mathrm{~mm}, 2 \mathrm{~mm})$, dan titik $5(5 \mathrm{~mm}, 8 \mathrm{~mm})$.

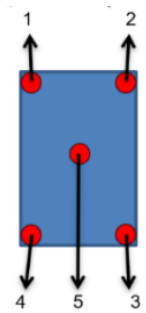

Gambar 4. Posisi Titik Pengambilan Data Temperatur Hasil Simulasi

\subsection{Hasil Simulasi Numerik}

Metode yang digunakan untuk simulasi numerik pada kasus perambatan panas pada pahat adalah metode Alternating Direct Implicit $(A D I)$. Berikut hasil visualisasi metode $A D I$ :

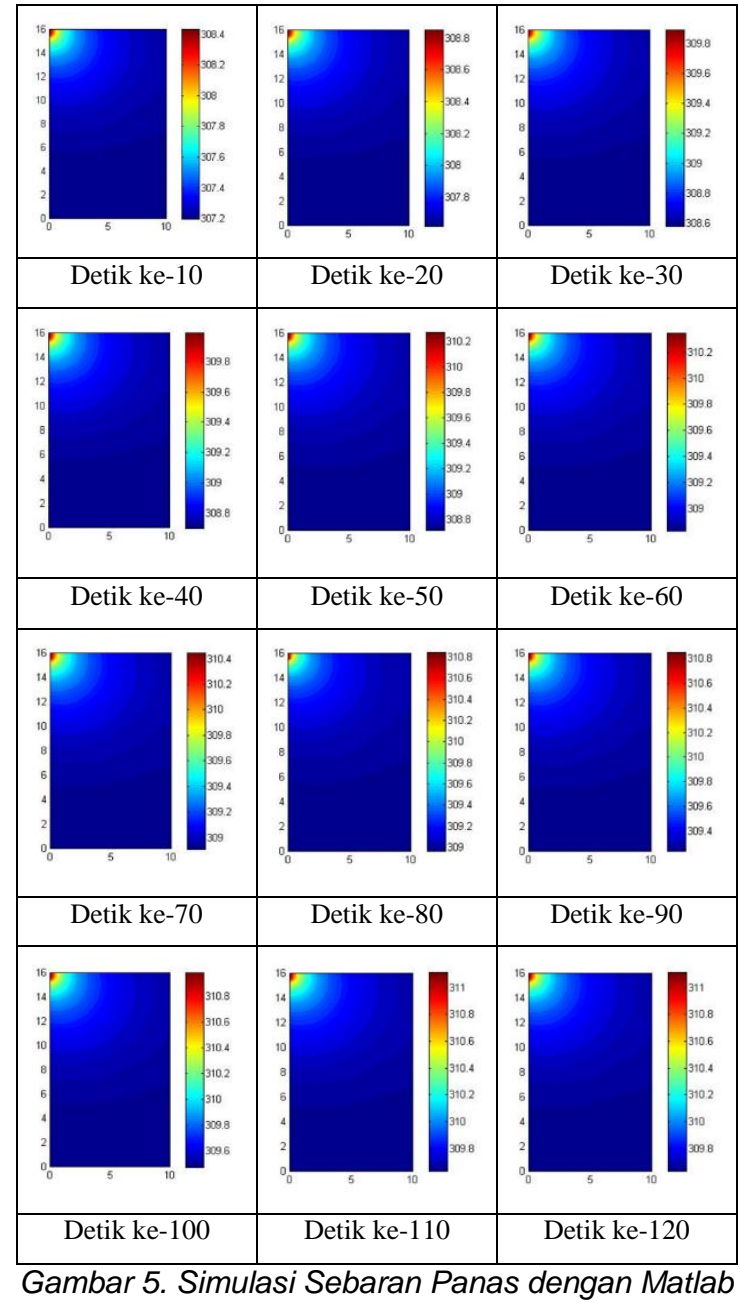

Data temperatur hasil simulasi numerik dengan metode $A D I$ pada Gambar 5 dituliskan dalam Tabel 1, dengan rentang waktu pengambilan data dari detik ke-10 
hingga detik ke-120. Posisi titik pengambilan data temperatur menyesuaikan dengan posisi titik pada Gambar 4.

Tabel 1. Data Hasil Komputasi

\begin{tabular}{cccccc}
\hline \multirow{2}{*}{$\begin{array}{c}\text { Waktu } \\
\text { (Detik) }\end{array}$} & \multicolumn{5}{c}{ Perhitungan Komputasi Suhu Pahat (Kelvin) } \\
\cline { 2 - 6 } & Titik 1 & Titik 2 & Titik 3 & Titik 4 & Titik 5 \\
\hline 10 & 307,49 & 307,25 & 307,18 & 307,18 & 307,22 \\
20 & 307,91 & 307,67 & 307,60 & 307,60 & 307,64 \\
30 & 308,90 & 308,64 & 308,56 & 308,56 & 308,61 \\
40 & 309,01 & 308,76 & 308,68 & 308,68 & 308,73 \\
50 & 309,09 & 308,79 & 308,68 & 308,68 & 308,75 \\
60 & 309,20 & 308,90 & 308,80 & 308,80 & 308,87 \\
70 & 309,28 & 308,99 & 308,88 & 308,88 & 308,95 \\
80 & 309,34 & 309,03 & 308,93 & 308,93 & 309,00 \\
90 & 309,63 & 309,31 & 309,21 & 309,21 & 309,28 \\
100 & 309,84 & 309,54 & 309,44 & 309,44 & 309,51 \\
110 & 309,99 & 309,70 & 309,60 & 309,60 & 309,67 \\
120 & 309,99 & 309,70 & 309,60 & 309,60 & 309,67 \\
\hline
\end{tabular}

\subsection{Hasil Eksperimen}

Data temperatur dari 5 titik permukaan pahat pada pengambilan data secara langsung dituliskan dalam Tabel 2, dengan rentang waktu pengambilan data dari detik ke-10 hingga detik ke-120. Posisi titik pengambilan data temperatur menyesuaikan dengan posisi titik pada Gambar 4.

Tabel 2. Data Hasil Pengujian

\begin{tabular}{cccccc}
\hline \multirow{2}{*}{$\begin{array}{c}\text { Waktu } \\
\text { (Detik) }\end{array}$} & \multicolumn{5}{c}{ Perhitungan Komputasi Suhu Pahat (Kelvin) } \\
\cline { 2 - 6 } & Titik 1 & Titik 2 & Titik 3 & Titik 4 & Titik 5 \\
\hline 10 & 278,00 & 307,36 & 307,38 & 308,08 & 308,00 \\
20 & 288,00 & 308,46 & 308,02 & 308,36 & 309,16 \\
30 & 298,00 & 308,88 & 308,44 & 308,80 & 309,44 \\
40 & 308,00 & 309,92 & 309,40 & 309,36 & 309,80 \\
50 & 318,00 & 310,02 & 309,52 & 309,40 & 309,88 \\
60 & 328,00 & 310,30 & 309,52 & 309,72 & 310,18 \\
70 & 338,00 & 310,38 & 309,64 & 309,96 & 310,22 \\
80 & 348,00 & 310,48 & 309,72 & 310,28 & 310,26 \\
90 & 358,00 & 310,57 & 309,76 & 310,40 & 310,56 \\
100 & 368,00 & 310,88 & 310,04 & 310,72 & 310,68 \\
110 & 378,00 & 311,02 & 310,28 & 310,72 & 310,72 \\
120 & 388,00 & 311,14 & 310,44 & 310,72 & 310,76 \\
\hline
\end{tabular}

\subsection{Perbandingan Hasil Simulasi Numerik dan Eksperimen}

Data temperatur pada Tabel 1 dan Tabel 2 disatukan dalam sebuah grafik hubungan antara waktu dengan temperatur. Gambar 6, Gambar 7, Gambar 8, Gambar 9 dan Gambar 10 berisi perbandingan antara temperatur hasil pengukuran dengan temperatur hasil komputasi, sehingga dapat diketahui tingkat ketepatan dan keselarasan tren perubahan temperatur yang terjadi. 


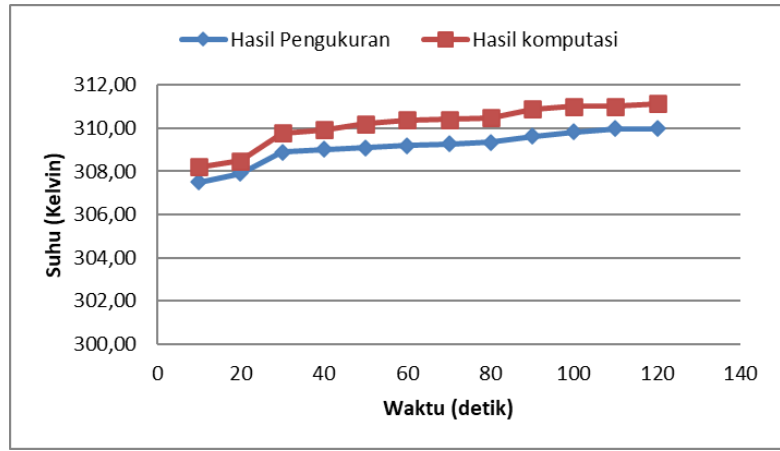

Gambar 6. Grafik hubungan antara waktu pemakanan dengan temperatur yang terjadi pada pahat iso 2 di titik 1.

Gambar 6 memperlihatkan peningkatan temperatur pada titik 1. Titik 1 merupakan titik utama sumber panas berasal. Pola peningkatan temperatur pada grafik hasil komputasi dengan grafik hasil pengukuran relatif sama, dan bentuk peningkatan temperatur seragam. Masih terjadi selisih temperatur antara hasil pengukuran dengan hasil komputasi, dengan selisih maksimal temperatur lebih kurang 1 derajat. Perbedaan temperatur terjadi karena beberapa faktor, diantaranya kepekaan alat pembaca suhu, ataupun kondisi temperatur lingkungan di sekitar pahat yang tidak bisa terukur secara tepat. Posisi titik 1 juga menjadi tantangan dalam pengambilan data, karena sesekali terhalang oleh tatal yang tersayat. Peningkatan temperatur selama 120 detik terjadi lebih kurang sebesar 2,5 derajat pada data pengukuran, dan 2,8 derajat pada data komputasi. Perbedaan ini masih dianggap relevan mengingat kepresisian alat ukur sebesar dua angka dibelakang koma.

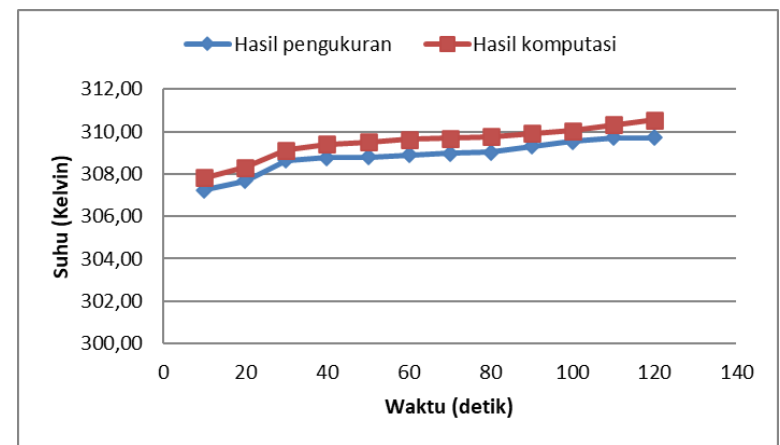

Gambar 7. Grafik hubungan antara waktu pemakanan dengan temperatur yang terjadi pada pahat iso 2 di titik 2.

Gambar 7 memperlihatkan pola peningkatan temperatur pada grafik hasil komputasi dengan grafik hasil pengukuran juga masih relatif sama. Selisih antara temperatur hasil pengukuran dengan temperatur hasil komputasi semakin kecil. Selisih maksimal temperatur lebih kurang 0,7 derajat.

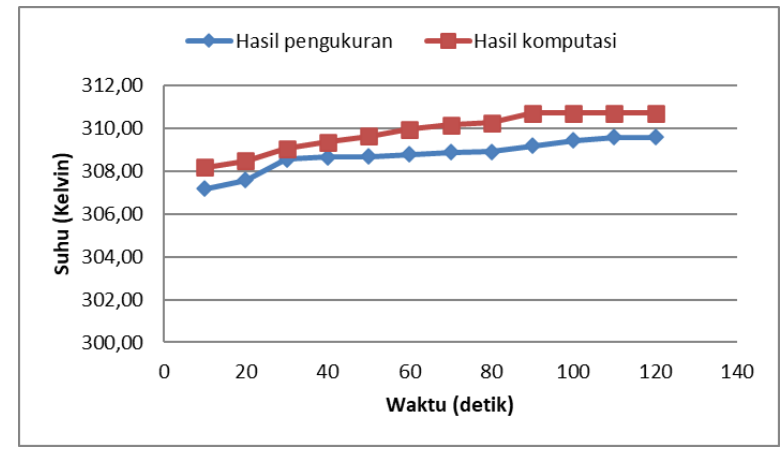

Gambar 8. Grafik hubungan antara waktu pemakanan dengan temperatur yang terjadi pada pahat iso 2 di titik 3. 
Gambar 8 memperlihatkan pola peningkatan temperatur pada grafik hasil komputasi dengan grafik hasil pengukuran relatif sama, dan masih terjadi selisih antara temperatur hasil pengukuran dengan temperatur hasil komputasi. Selisih maksimal temperatur lebih kurang 1,3 derajat. Dari Gambar 8 terlihat bahwa temperatur hasil komputasi mengalami steady pada detik ke-110. Hal ini semakin menunjukkan bahwa kondisi lingkungan sangat mempengaruhi hasil pengukuran, terlebih posisi titik 3 berada paling jauh dari sumber panas di titik 1 .

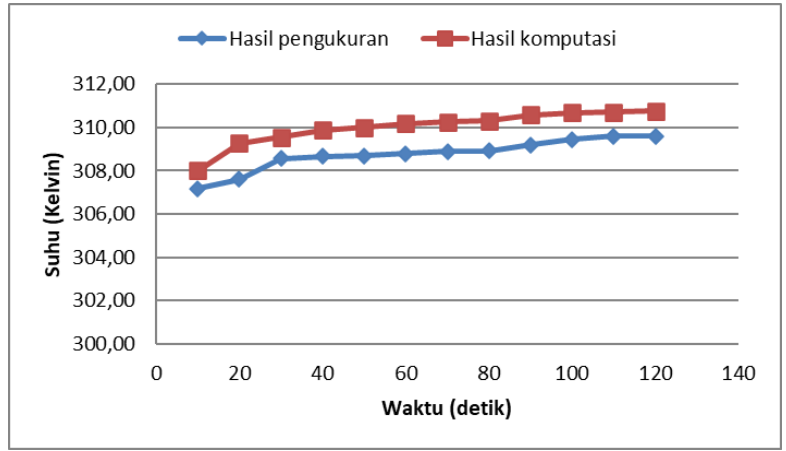

Gambar 9. Grafik hubungan antara waktu pemakanan dengan temperatur yang terjadi pada pahat iso 2 di titik 4.

Gambar 9 memperlihatkan pola peningkatan temperatur pada grafik hasil komputasi dengan grafik hasil pengukuran relatif sama, dan bentuk peningkatan temperatur yang seragam. Pada gambar memperlihatkan selisih antara temperatur hasil pengukuran dengan temperatur hasil komputasi masih terjadi. Selisih maksimal temperatur lebih kurang 1,6 derajat.

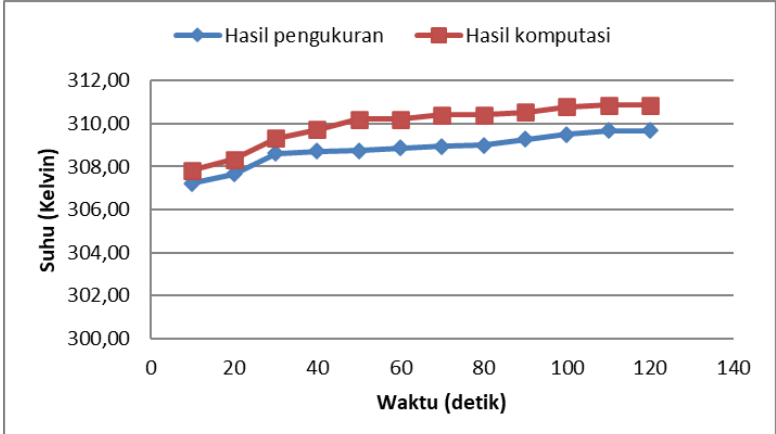

Gambar 10. Grafik hubungan antara waktu pemakanan dengan temperatur yang terjadi pada pahat iso 2 di titik 5.

Gambar 10 memperlihatkan pola peningkatan temperatur pada grafik hasil komputasi dengan grafik hasil pengukuran relatif sama. Bentuk peningkatan temperaturnya juga seragam. Perbedaan temperatur hasil pengukuran dengan hasil komputasi masih terjadi. Selisih maksimal perbedaan temperatur lebih kurang 1,3 derajat.

\section{Kesimpulan}

Semua proses pembubutan menimbulkan panas. Panas yang timbul akibat gesekan di antara sisi potong pahat dengan material yang disayat akan menyebar menuju mata potong pahat dan material yang disayat. Penelitian yang dilakukan menghasilkan data sebaran panas pada permukaan pahat karbida. Beberapa hal yang dapat disimpulkan dari pengamatan data-data tersebut diantaranya:

1. Temperatur maksimal hasil komputasi sebesar 309,99 Kelvin di titik 1, dan mulai stabil pada detik ke-110. Temperatur terendah hasil komputasi berada pada titik 3 dan 4 sebesar 309,60 Kelvin, dan mulai stabil pada detik ke-110. 
2. Temperatur maksimal hasil pengujian sebesar 388,00 Kelvin di titik 1 pada detik ke-120, saat akhir pengujian. Temperatur terendah hasil komputasi berada di titik 3 sebesar 310,44 Kelvin pada detik ke-120, saat akhir pengujian.

3. Selisih maksimal temperatur hasil pengukuran dan temperatur hasil komputasi sebesar 1,68 derajat pada titik ke-4 detik ke-20, sedangkan selisih minimalnya 0,48 derajat pada titik ke-2 detik ke-30. Rata-rata selisih sebesar 1,03 derajat.

4. Tren sebaran panas hasil komputasi dan pengujian relatif sama. Temperatur hasil pengukuran memiliki selisih yang relatif sama dengan temperatur hasil komputasi, namun rata-rata berada lebih rendah dibanding temperatur hasil komputasi. Hal ini disebabkan oleh kemampuan pembacaan data temperatur oleh laser termometer yang terlambat dibanding temperatur yang saat itu muncul.

\section{Daftar Pustaka}

[1] Holman, J.P., 1997, Perpindahan Kalor, Jakarta: Erlangga.

[2] Al-Odat, M.Q., 2009, Emerald Journal, "Numerical analysis of cutting tool temperature in dry machining processes with embedded heat pipe", Saudi Arabia.

[3] Fahendri, Festiyed, dan Hidayati, Analisa Numerik Distribusi Panas Tak Tunak pada Heatsink dengan Metoda Finite Different. Pillar of Physics, Vol. 4, November 2014, pp 81-88

[4] Karina, FAP., 2018, Penyelesaian Persamaan Panas Satu dan Dua Dimensi dengan Menggunakan Metode Beda Hingga, Skripsi. Yogyakarta: Universitas Sanata Dharma

[5] Dhawan, Sharanjeet dan Khumar, Sheo, 2009, International Journal Research and Reviews in Applied Sciences, "A comparative study of numerical techniques for 2D transient heat conduction equation using finite element method", India.

[6] Durmin dan Hanafi,L., Studi Perbandingan Perpindahan Panas Menggunakan Metode Beda Hingga dan Crank-Nicholson, Jurnal Limits ITS, Vol 1, No 1, 2015

[7] Buchori, L., Bindar, Y., dan Istadi, Komputasi perpindahan panas konduksi dua dimensi untuk konveksi dan radiasi thermal. Prosiding Seminar Nasional Rekayasa Kimia dan Proses, 2000.

[8] Supriyanto J., Budiana P.B., dan Widodo P.J., Simulasi Numerik Perpindahan Panas 2 Dimensi pada Proses Pendinginan Tembaga Murni dengan Variasi Cetakan Pasir dan Mullite Menggunakan Pendekatan Beda Hingga. Mekanika, Vol 13, No 1, September 2014.

[9] Rachmawati V., dan Kamiran, Simulasi Perpindahan Panas pada Lapisan Tengah Pelat Menggunakan Metode Elemen Hingga. Jurnal Sains dan Seni ITS, Vol 4., No. 2., 2015.

[10] Harina A.M., dan Ichsani D., Studi Simulasi Numerik dan Eksperimental Pengaruh Penambahan Fin Berbentuk Prisma Segitiga yang Dimiringkan Terhadap Arah Aliran yang Dipasang pada Bagian Bawah Plat Absorber Berbentuk V Terhadap Efisiensi Kolektor Surya Pemanas Udara. Jurnal Teknik ITS, Vol 5., No 2., 2016. 